\title{
Perceived stress in elderly stroke survivors after hospital discharge to home
}

\author{
Estresse percebido nos idosos sobreviventes do AVC após a alta hospitalar para casa \\ Estrés notado en los ancianos supervivientes de AVC luego de alta hospitalaria
}

Emanuella Barros dos Santos ${ }^{1}$, Rosalina Aparecida Partezani Rodrigues ${ }^{1}$, Sueli Marques ${ }^{1}$, Octávio Marques Pontes-Neto ${ }^{2}$

${ }^{1}$ Universidade de São Paulo, Escola de Enfermagem de Ribeirão Preto, Ribeirão Preto, SP, Brazil.

${ }^{2}$ Universidade de São Paulo, Faculdade de Medicina de Ribeirão Preto, Ribeirão Preto, SP, Brazil.

\begin{abstract}
Objective: To evaluate the relationship between perceived stress and comorbidities, neurological deficit, functional independence and depressive symptoms of stroke survivors after hospital discharge. Method: Cross-sectional study with 90 elderly stroke survivors. The National Institutes of Health Stroke Scale instrument, the Functional Independence Measure instrument, the Geriatric Depression Scale and the Perceived Stress Scale were used. Bivariate Pearson correlation, independent $t$ test and multiple regression analysis were used to evaluate the relationship between perceived stress and other variables. Results: The final regression model showed that higher perceived stress was related to less functional independence $(p=0.022)$ and more depressive symptoms ( $p$ <0.001). Conclusion: At hospital discharge, interventions should be planned for the treatment of depressive symptoms and to create adaptation strategies to the reduction of functional independence, in order to reduce the stress of the survivors.
\end{abstract}

DESCRIPTORS

Aged; Stroke; Stress, Psychological; Activities of Daily Living; Depression.
Corresponding author:

Rosalina Aparecida Partezani Rodrigues

Universidade de São Paulo, Escola de

Enfermagem de Ribeirão Preto

Av. Bandeirantes, 3900 - Bairro Monte Alegre

CEP 14040-902 - Ribeirão Preto, SP, Brazil

rosalina@eerp.usp.br
Received: $11 / 28 / 2014$

Approved: 05/23/2015 


\section{INTRODUCTION}

Stroke is the second leading cause of death ${ }^{(1)}$ and the third most common cause of disability-adjusted life years worldwide ${ }^{(2)}$. The absolute number of people with first stroke has increased by $68 \%$ over the past decades throughout the world. Furthermore, the number of people who survived a stroke increased by $84 \%$. If this trend continues, by the year 2030 the world will have 70 million stroke survivors ${ }^{(3)}$.

In Brazil, although the mortality rates due to stroke have decreased across the country between 2004 and $2009^{(4)}$, this disease remains a leading cause of death ${ }^{(5)}$. Current trends in the incidence of stroke in the country are still unknown. However, due to population aging, epidemiological transition and reduction of stroke lethality in middle-income countries, such as Brazil, an increase in the incidence of this disease is expected to occur, as well as the number of survivors and the disability-adjusted life years ${ }^{(3)}$.

For the survivor, returning home after hospitalization due to stroke is, at first, a time of joy and attempt to restore normality ${ }^{(6)}$. However, once they realize that they cannot carry out the activities of everyday life as before and that there was loss of their daily routine, coming back home becomes a challenging experience and a critical period ${ }^{(7)}$. That is when survivors realize the true impact and repercussions of stroke in their lives ${ }^{(6,8)}$. They begin to make comparisons of the current life with the previous life before the stroke in an attempt to reconcile their identity and the desire to go back to being who they were before ${ }^{(8)}$.

A major event, such as stroke, can make the survivors' lives very stressful ${ }^{(9)}$. According to the transactional theory of stress, psychological stress is a particular relationship between the individual and the environment, which is assessed by them as they go beyond their coping resources, threatening their well-being ${ }^{(9)}$. This evaluation is a process that defines why and to what extent certain relationship between the individual and the environment that surrounds $\mathrm{him} /$ her is stressful. In this relationship, it is not the quality of the event that will rank it as a stressor, but the way it is perceived and interpreted by the individual ${ }^{(9)}$.

Studies have shown that stress experienced by stroke survivors after hospital discharge is directly related to their functional independence ${ }^{(10-11)}$ and the presence of depressive symptoms ${ }^{(11)}$. Stroke survivors with lower functional independence ${ }^{(10-11)}$ and greater depressive symptoms ${ }^{(11)}$ have a higher level of stress back home after hospital discharge.

Psychological stress can be detrimental to the lives of stroke survivors. When it persists for a long period, stress can cause changes in emotional behavior, social function, intellectual processes, in spiritual beliefs, causing suffering, it makes communication less effective and contribute to the development of disease ${ }^{(9)}$.

Despite the great impact that psychological stress can cause in the lives of stroke survivors, the scientific production on the perceived stress and its predictors remains scarce. Most publications which make the connection between "stress and stroke" refers to the physiological stress (e.g. oxidative stress in cells) or the adaptation and the family burden facing disabilities of their family member survivor of stroke, with a few exceptions ${ }^{(10-11)}$.

Given these considerations, this study aimed to evaluate the relationship between perceived stress and clinical variables (comorbidities, neurological deficit, functional independence and depressive symptoms) and sociodemographic variables of elderly stroke survivors after hospital discharge.

\section{METHOD}

\section{TYPE OF STUDY AND PARTICIPANTS}

This is an observational and cross-sectional study. The population consisted of elderly stroke survivors treated at the Emergency Unit of the Clinics Hospital of Ribeirao Preto Medical School (HCFMRP-USP). The sample size included the elderly stroke survivors treated between January 2011 and January 2012 and who met the following inclusion criteria: (1) age equal or over 60 years; (2) medical diagnosis of the first stroke event; (3) living in the districts of XIII Regional Health Department (DRS-13); (4) being able to communicate verbally; and (5) with preserved cognitive function.

For the assessment of cognitive function, we used the Brazilian version of the Mini Mental State Examination (MMSE). The cut-off point, adapted to the educational level of the population, is 13 for illiterate, 18 for those who studied between 1 and 8 years and 26 for those who studied for more than eight years ${ }^{(12)}$. Exclusion criteria were: (1) having a neurological comorbidity; (2) living in an Institution for the Aged (IA); and (3) presenting global aphasia. The flowchart of the selection of the study sample is shown in Figure 1.

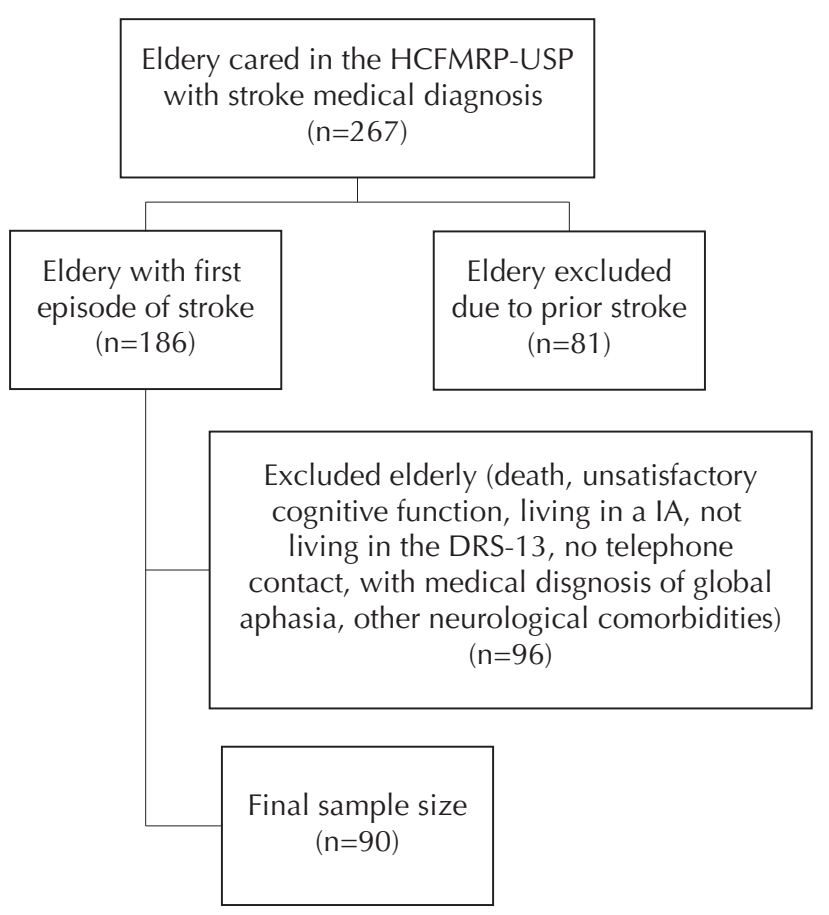

Figure 1 - Flowchart of the selection of the study sample - Ribeirao Preto, SP, Brazil, 2011-2012. 


\section{VARIABLES OF THE STUDY}

The dependent variable of this study is the perceived stress (score of the Perceived Stress Scale - 10 items) and the independent variables are: age (years); gender (female, male); residence status (live alone or with someone); presence of caregiver (whether or not there is a formal or informal caregiver); comorbidities (number of comorbidities); neurological deficit (score from the National Institutes of Health Stroke Scale); functional independence (Functional Independence Measure score); depressive symptoms (score of the Geriatric Depression Scale - 15 items).

\section{Procedures}

Firstly, the stroke survivors were identified through medical records. After hospital discharge, we contacted them by telephone to invite them to participate and to schedule the date for the data collection, if they were in agreement. Data collection was conducted from January 2011 to January 2012, in the home of the elderly, two weeks after discharge by a trained nurse to implement the instruments.

\section{INSTRUMENTS}

To collect socio-demographic data we used a structured script containing the following variables: age (years), gender, education (years of formal education), marital status (single, married, divorced, and widowed), residence status (alone or living with someone) and presence of caregiver (whether or not there was a formal or informal caregiver). The type of stroke and comorbidities were collected from medical records.

Neurological deficit was assessed through the Brazilian version of the National Institutes of Health Stroke Scale $(\text { NIHSS })^{(13)}$. This is a scale of systematic use that allows a quantitative assessment of the neurological deficits associated with stroke, consisting of 15 items that assess the following areas: awareness, vision, extraocular movements, facial paralysis, muscle strength in the limbs, ataxia, sensitivity, speech and language. The total score ranges from 0 to 42 points, with higher scores suggesting greater neurological impairment. According to the NIHSS score, stroke can be classified as: mild $(<4)^{(14)}$, moderate $(\geq 4$ to $\leq 15)$ and severe $(>15)$. The Brazilian version of this scale showed intra-class correlation coefficient of $0.902(95 \% \mathrm{CI}=0.84-0.94)^{(13)}$.

The Brazilian version of the Functional Independence Measure (FIM) ${ }^{(15)}$ was used to assess the degree of assistance required by stroke survivors to perform activities of daily living. This scale is divided into two subscales, motor and cognitive, and consists of 18 items assessing performance in self-care, sphincter control, transportation, locomotion, communication and social cognition. The score of each item can vary from 1 (total dependence) to 7 (total independence). The score of the motor subscale varies between 13 and 91 points; cognitive subscale between 5 and 35 points. The FIM score varies from 18 to 126, with higher scores indicating greater functional independence. In the Brazilian version, the FIM subscales showed good correlation with test-retest reliability (Pearson: 0.91 to 0.98 ; CI: 0.91 to 0.98 ) and between the two observers (Pearson: 0.87 to 0,98 CI: $0.87-0.98)^{(15)}$.

To assess depressive symptoms, we used the Brazilian version of the Geriatric Depression Scale, 15 items (GDS$15)^{(16)}$. This scale consists of 15 items, having dichotomous response (yes or no) to the questions. The score scale ranges from 0 to 15 points, with scores greater than or equal to 6 indicating the presence of depressive symptoms. The Brazilian version of the scale had good correlation with test-retest (rho $=0.86 ; \mathrm{p}<0.001)$ and kappa coefficient of $0.64^{(16)}$.

The Brazilian version of the Perceived Stress Scale, 10 items (PSS-10), ${ }^{(17)}$ was used to measure the degree to which individuals perceive situations or events as stressful. Each item consists of statements that should be scored from 0 to 4 , according to the frequency in which they occur. Total scores can range from 0 to 40 , with higher scores suggesting higher levels of stress. This scale has no cut-off point for the stress level classification. The Brazilian version of PSS-10 showed reliability coefficient of $0.83^{(17)}$.

\section{ETHICAL CONSIDERATIONS}

The research followed the ethical precepts of the $\mathrm{Na}$ tional Health Council Resolution 196/1996, and was conducted after approval by the Research Ethics Committee of the Ribeirao Preto Medical School - USP, protocol No. 10358/210 and CEP-FMRP/USP - 3577/2010. All participants who were asked to participate in the study agreed to sign the consent form $(\mathrm{CF})$.

\section{Statistical anAlysis}

The data were imported into the software Statistical Package for Social Sciences (SPSS) for Windows, version 21.0, for analysis. Descriptive statistics technique was used for all variables. Bivariate Pearson correlation, independent $t$ test and multiple regression analysis were used to evaluate the relationship between perceived stress and other variables.

A series of multiple regression analysis was performed to find the model that best explained the perceived stress (PSS-10). Two blocks of variables were constructed: block of sociodemographic variables (gender, age, residence status, presence of caregiver) and group of clinical variables (comorbidities, NIHSS, FIM, GDS-15). Each block was analyzed separately and statistically significant variables of each block are added to the final model. The level of significance was set at $\alpha<0.05$.

\section{RESULTS}

The sociodemographic characteristics of 90 stroke survivors are shown in Table 1 . The mean age was $71.2(\mathrm{SD}=$ 8.4), ranging between 60 and 94 years. There was no difference between the mean age for men and women $(\mathrm{p}=$ 0.225). Most married survivors (77\%) were male. About $90 \%$ of stroke survivors lived with someone, being more frequent those living with spouse (22.1\%) and spouse and son/ daughter (21.1\%). Among the survivors who had caregivers, 
$35 \%$ received care from their son/daughter and $33.3 \%$ from their spouses.

Table 1 - Distribution of stroke survivors, according to sociodemographic variables - Ribeirao Preto, SP, Brazil, 2011-2012.

\begin{tabular}{|c|c|c|}
\hline Variables & Absolute number (n) & Percentage $(\%)$ \\
\hline \multicolumn{3}{|l|}{ Gender } \\
\hline Female & 39 & 43.3 \\
\hline Male & 51 & 56.7 \\
\hline \multicolumn{3}{|l|}{ Age (years) } \\
\hline $60-64$ & 23 & 25.6 \\
\hline $65-69$ & 20 & 22.2 \\
\hline $70-74$ & 17 & 18.9 \\
\hline $75-79$ & 11 & 12.2 \\
\hline 80 and over & 19 & 21.1 \\
\hline \multicolumn{3}{|l|}{ Marital status } \\
\hline Single & 6 & 6.7 \\
\hline Married & 48 & 53.3 \\
\hline Divorced/Separated & 36 & 40 \\
\hline \multicolumn{3}{|c|}{ Education (years in formal education) } \\
\hline None & 24 & 26.7 \\
\hline $1-4$ & 50 & 55.6 \\
\hline $5-8$ & 10 & 11.1 \\
\hline $9-12$ & 3 & 3.3 \\
\hline 13 and over & 3 & 3.3 \\
\hline \multicolumn{3}{|l|}{ Presence of caregiver } \\
\hline Yes & 45 & 50 \\
\hline No & 45 & 50 \\
\hline
\end{tabular}

As for the type of stroke, $92.2 \%$ of survivors have suffered an ischemic stroke. The mean number of comorbidity was $2.44(\mathrm{SD}=1.35)$. The three most frequent comorbid conditions were hypertension (86.7\%), diabetes mellitus $(37.8 \%)$ and heart disease (32.2\%). Forty-six stroke survivors $(51 \%)$ had three or more comorbid conditions.

The mean, standard deviation and median of NIHSS, FIM, GDS-15 and PSS-10 variables of the stroke survivors, collected after hospital discharge, are shown in Table 2. The mean PSS-10 score was 14.04 (95\% CI 12.26-15.85).

Table 2 - Distribution of values (mean, standard deviation, median, minimum and maximum) of the NIHSS, FIM (total, cognitive and motor), GDS-15 and PSS-10 of the stroke survivors - Ribeirao Preto, SP, Brazil, 2011-2012.

\begin{tabular}{lccc}
\hline Variables & Mean $(\mathrm{SD})$ & Median & Variation \\
\hline NIHSS & $3.73(4.5)$ & 2 & $0-18$ \\
FIM (total) & $102.99(24.1)$ & 115 & $45-126$ \\
Cognitive FIM & $33.11(2.36)$ & 34 & $22-35$ \\
Motor FIM & $69.89(23.08)$ & 80 & $15-91$ \\
GDS-15 & $3.47(3.03)$ & 2.5 & $0-10$ \\
PPS-10 & $14.04(8.5)$ & 13 & $2-38$ \\
\hline
\end{tabular}

As for stroke severity, $68.9 \%$ suffered mild stroke, $27.8 \%$ moderate and $3.3 \%$ severe. According to the FIM, $70 \%$ of stroke survivors had modified independence to perform activities of daily living. Twenty-five survivors (27.7\%) had depressive symptoms, according to GDS- 15 .

There was no difference between the means of the PSS-10 with respect to gender $(\mathrm{p}=0.134)$ and residence status $(\mathrm{p}=$ $0.08)$. There was also no relationship between age and perceived stress $(r=-0.02, p=0.85)$. The difference between the mean of the PSS-10 survivors with and without a caregiver was 8.13 ( $p<0.001)$. There was no relationship between the number of comorbidities and perceived stress $(r=0.167, p=$ 0.116). Higher level of perceived stress was related to worse neurological deficits (NIHSS) $(\mathrm{r}=0.534, \mathrm{p}<0.001)$, greater impairment of cognitive function (cognitive FIM) $(r=-0.363$, $\mathrm{p}<0.001)$ and motor (motor FIM) $(\mathrm{r}=-0.545, \mathrm{p}<0.001)$ and more depressive symptoms (GDS-15) $(\mathrm{r}=0.604, \mathrm{p}<0.001)$.

After the completion of multiple regressions in blocks of sociodemographic and clinical variables, the variables were statistically significant for "presence of caregiver", FIM and GDS-15. Therefore, the final model contained these variables, as shown in Table 3 . This model explained $63 \%$ of the variation in PPS-10 score, which was significant $\left(\mathrm{F}_{3 ; 86}=51.48, \mathrm{p}\right.$ $<0.001)$. Higher perceived stress level was associated with lower functional independence and more depressive symptoms.

Table 3 - Multiple linear regression model with three explanatory variables for perceived stress (PPS-10) - Ribeirao Preto, SP, Brazil, 2011-2012.

\begin{tabular}{lccc}
\hline Model & B & $\mathbf{9 5} \% \mathbf{C I}$ for $\mathbf{B}$ & p-value \\
\hline Constant & 18.39 & $(12.39 ; 24.38)$ & 0.000 \\
FIM (total) & -0.08 & $(-0.15 ;-0.01)$ & 0.022 \\
GDS-15 & 1.77 & $(1.37 ; 2.17)$ & 0.000 \\
Presence of caregiver & -1.60 & $(-4.72 ; 1.51)$ & 0.308 \\
\hline
\end{tabular}

\section{DISCUSSION}

Suffering Stroke is an unexpected episode and it brings abrupt changes in the survivor's life ${ }^{(18)}$, with high potential to be experienced in a stressful way, since it represents threat to the sense of personal control. Our findings suggest that the perceived stress of stroke survivors is related to functional independence and depressive symptoms. Other authors reported similar results ${ }^{(10-11)}$. In a longitudinal study conducted in Texas on the perceived stress of 159 stroke survivors ${ }^{(10)}$, it was noticed that the survivors with lower functional independence had higher stress level in the first year after discharge. Similarly, in a cross-sectional study with 97 stroke survivors, there was a negative relationship between the perceived stress and the functional independence of the survivors immediately after hospital discharge ${ }^{(11)}$.

The relationship between stress and the functional independence is quite plausible. The total or partial loss of independence is one of the most difficult transition experiences for stroke survivors ${ }^{(6,7-18)}$. For them, participation in activities of daily living is something more than the fulfilment of their routine; it represents their identity/existence and satisfaction in a dynamic process ${ }^{(7)}$. The need for assistance to carry out activities of daily living can arouse feelings of loss of control over one's life and even loss of identity. As a result of identity 
conflict and the feeling of being unable to manage his/her own life, stroke survivors describe their lives as stressful, challenging and difficult to handle $\mathrm{e}^{(7)}$.

It is noteworthy that the sample of this study consists only of the elderly. At this stage of life, people have to adapt to a range of age-related physical, psychological and psychosocial aspects. The elderly experience many losses, including declining health, loss of professional activities, or the death of friends and spouses ${ }^{(19)}$. Consequently, the age factor alone generates many demands that the elderly has to adapt. The occurrence of stroke and therefore, the sudden reduction of functional independence can generate new demands that may require resources beyond that the elderly has, when that happens, they experience stress.

The return to their home after hospital discharge is accompanied by many changes in the lives of stroke survivors and those changes can cause feelings of frustration, anger, sadness, loss, pain and depression ${ }^{(8)}$. Our results suggested that the depressive symptom is another factor associated with perceived stress of stroke survivors after hospital discharge. Our findings are consistent with the results of crosssectional study that aimed to identify predictors of perceived stress of 97 stroke survivors immediately after discharge, which showed that more depressive symptoms were related to higher levels of perceived stress ${ }^{(11)}$. Similarly, a study conducted in the state of Georgia, in the United States, also found a strong positive correlation between perceived stress and depressive symptoms in stroke survivors, regardless of the cerebral hemisphere affected by the stroke ${ }^{(20)}$.

Due to the study design, we cannot infer that stress causes depressive symptoms or depressive symptoms cause stress, however, we can only suggest that these two variables have a strong positive correlation. In the literature, there is strong evidence indicating that stress plays a causal role in many cases of depression ${ }^{(21)}$. It should be noted that depression is an important variable for the sample of our study, since it is a frequent comorbidity among the elderly. The prevalence of depression in this population varies between $0.9 \%$ and $42 \%{ }^{(22)}$. It remains unclear whether the prevalence of depression increases or decreases with age. In a systematic review on the relationship between age and risk of depression held in 2012, suggested that advanced age seems to be an important risk factor for depression in the elderly population with age lower than 80 years $^{(23)}$. Given these data and the assumption that stress causes de- pression, for the elderly stroke survivors, stress would be a risk factor for depression in addition to the age factor.

The transactional theory of stress postulates that catastrophic events, such as stroke, produce physical and psychosocial outcomes that need to be identified and treated so that adaptation occurs ${ }^{(9)}$. The functional independence and depressive symptoms were presented in our study as factors related to the stress of stroke survivors after discharge. Therefore, health professionals must anticipate and perform screening for identification and treatment of depressive symptoms and implement interventions to adapt the reduced functional independence, both at the time of hospital discharge as back home through monitoring services in order to make the transition from hospital to their homes less chaotic and stressful for the stroke survivor.

Some limitations of this study should be considered. The major limitation of the study was to evaluate the stress and related variables in only a moment. Longitudinal studies should be conducted to evaluate how the stress of stroke survivors is presented over time and what are the predictors of stress perceived at three, six or twelve months after discharge. The exclusion of survivors with cognitive and aphasic deficit is another limitation, as these survivors may experience higher levels of stress ${ }^{(24)}$ and other related factors.

\section{CONCLUSION}

Returning to their home after hospital discharge is a critical time in the lives of stroke survivors. Changes resulting from stroke have great potential to be experienced as stressful by its survivors.

Our results suggested that the perceived stress in elderly stroke survivors after hospital discharge is correlated with depressive symptoms and functional independence as higher stress level of stroke survivors is related to lower functional independence and to as many depressive symptoms.

Health professionals should consider depressive symptoms and reduction of functional independence at hospital discharge. The discharge plan and interventions for stroke survivors should be designed and targeted for the treatment of depressive symptoms and strategies to adapt the reduced independence in order to reduce the stress of life of the survivors, and to facilitate their recovery and reintegration to the community.

\section{RESUMO}

Objetivo: Avaliar a relação entre o estresse percebido e comorbidades, déficit neurológico, independência funcional e sintomas depressivos dos sobreviventes do Acidente Vascular Cerebral (AVC) após a alta. Método: Estudo transversal com 90 idosos sobreviventes do AVC. Foram utilizados os instrumentos National Institutes of Health Stroke Scale, Medida da Independência Funcional, Escala de Depressão Geriátrica e a Escala de Estresse Percebido. Correlação bivariada de Pearson, teste t independente e análise de regressão múltipla foram utilizados para avaliar as relações entre o estresse percebido e as outras variáveis. Resultados: $\mathrm{O}$ modelo final da regressão evidenciou que maior estresse percebido estava relacionado à menor independência funcional $(\mathrm{p}=0,022)$ e ao maior número de sintomas depressivos ( $\mathrm{p}<$ 0,001). Conclusão: No momento da alta para casa, intervenções devem ser planejadas para o tratamento dos sintomas depressivos e para criar estratégias de adaptação à redução da independência funcional, a fim de reduzir o estresse dos sobreviventes.

\section{DESCRITORES}

Idoso; Acidente Vascular Cerebral; Estresse Psicológico; Atividades Cotidianas; Depressão. 
RESUMEN

Objetivo: Evaluar la relación entre el estrés percibido y comorbilidades, déficit neurológico, independencia funcional y síntomas depresivos de los supervivientes del Accidente Vascular Cerebral (AVC) después del alta. Método: Estudio transversal con 90 ancianos supervivientes de AVC. Fueron empleados los instrumentos National Institutes of Health Stroke Scale, Medida de la Independencia Funcional, Escala de Depresión Geriátrica y Escala de Estrés Percibido. Correlación bivariada de Pearson, prueba t independiente y análisis de regresión múltiple fueron utilizados para valorar las relaciones entre el estrés percibido y las otras variables. Resultados: El modelo final de la regresión evidenció que el mayor estrés percibido estaba relacionado con la menor independencia funcional $(\mathrm{p}=0,022)$ y el mayor número de síntomas depresivos $(\mathrm{p}<0,001)$. Conclusión: En el momento del alta hospitalaria, se deben planificar las intervenciones para el tratamiento de los síntomas depresivos y para crear estrategias de adaptación a la reducción de la independencia funcional, a fin de reducir el estrés de los supervivientes.

\section{DESCRIPTORES}

Anciano; Accidente Cerebrovascular; Estrés Psicológico; Actividades Cotidianas; Depresión.

\section{REFERENCES}

1. Lozano R, Naghavi M, Foreman K, Lim S, Shibuya K, Aboyans V, et al. Global and regional mortality from 235 causes of death for 20 age groups in 1990 and 2010: a systematic analysis for the Global Burden of Disease Study 2010. Lancet. 2012; 380(9859):2095-128.

2. Murray CJ, Vos T, Lozano R, Naghavi M, Flaxman AD, Michaud C, et al. Disability-adjusted life-years (DALYs) for 291 diseases and injuries in 21 regions, 1990-2010: a systematic analysis for the Global Burden of Disease Study 2010. Lancet. 2012; 380(9859):2197-223.

3. Feigin VL, Forouzanfar MH, Krishnamurthi R, Mensah GA, Connor M, Bennett DA, et al. Global and regional burden of stroke during 1990-2010: findings from the Global Burden of Disease Study 2010. Lancet. 2014;18;383(9913):245-54.

4. Lotufo PA, Goulart AC, Fernandes TG, Benseñor IM. A reappraisal of stroke mortality trends in Brazil (1979-2009). Int J Stroke. 2013;8(3):155-63.

5. Brasil. Ministério da Saúde. DATASUS. Sistemas de Informação sobre Mortalidade (SIM) [Internet]. Brasília; 2012 [citado 2014 set. 26 ]. Disponível em: http://tabnet.datasus.gov.br/cgi/tabcgi.exe?sim/cnv/obt10uf.def

6. Eilertsen G, Kirkevold M, Bjørk IT. Recovering from a stroke: a longitudinal, qualitative study of older Norwegian women. J Clin Nurs. 2010;19(13-14):2004-13.

7. Fallahpour M, Jonsson H, Joghataei MT, Nasrabadi AN, Tham K. "I am not living my life": lived experience of participation in everyday occupations after stroke in Tehran. J Rehabil Med. 2013;45(6),528-34.

8. Lutz BJ, Young ME, Cox KJ, Martz C, Creasy KR. The crisis of stroke: experiences of patients and their family caregivers. Top Stroke Rehabil. 2011;18(6):786-97.

9. Lazarus RS, Folkman L. Stress, coping and adaptation. New York: Springer; 1984.

10. Ostwald SK, Bernal MP, Cron SG, Godwin KM. Stress experienced by stroke survivors and spousal caregivers during the first year after discharge from inpatient rehabilitation. Top Stroke Rehabil. 2009;16(2):93-104.

11. Ostwald SK, Swank PR, Khan MM. Predictors of functional independence and stress level of stroke survivors at discharge from inpatient rehabilitation. J Cardiovas Nurs. 2008;23(4):371-77.

12. Bertoluccil PHF, Bruckil SMD, Campaccil SR, Juliano Y. O Mini-Exame do estado mental em uma população geral: impacto da escolaridade. Arq Neuro-Psiquiatr. 1994;52(1):1-7.

13. Cincura C, Pontes-Neto OM, Neville IS, Mendes HF, Menezes DF, Mariano DC, et al. Validation of the National Institutes of Health Stroke Scale, modified Rankin Scale and Barthel Index in Brazil: the role of cultural adaptation and structured interviewing. Cerebrovasc Dis. 2009;27(2):119-22.

14. Fischer U, Baumgartner A, Arnold M, Nedeltchev K, Gralla J, De Marchis GM, et al. What is a minor stroke? Stroke. 2010;41(4):661-6.

15. Riberto M, Miyazaki MH, Jorge Filho D, Sakamoto H, Battistella LR. Reprodutibilidade da versão brasileira da Medida de Independência Funcional. Acta Fisiatr. 2001;8(1):45-52.

16. Almeida OP, Almeida SA. Confiabilidade da versão brasileira da escala de depressão em geriatria (GDS) versão reduzida. Arq NeuroPsiquiatr. 1999;57(2b):421-6.

17. Luft CB, Sanches SO, Mazo GZ, Andrade A. Versão brasileira da Escala de Estresse Percebido: tradução e validação para idosos. Rev Saúde Pública. 2007;41(4):606-15.

18. Taule T, Raheim M. Life changed existentially: a qualitative study of experiences at 6-8 months after mild stroke. Disabil Rehabil. 2014;36(25):2107-19.

19. Aldwin CM, Sutton KJ, Chiara G, Spiro A 3rd. Age differences in stress, coping, and appraisal: findings from the normative aging study. J Gerontol B Psychol Sci Soc Sci. 1996;51(4):179-88.

20. Laures-Gore JS, Defife LC. Percieved stress and depression in left and right hemisphere post-stroke patients. Neuropsychol Rehabil. 2013;23(6):783-97.

21. Hammen C. Stress and depression. Annu Rev Clin Psychol. 2005;1:293-319.

22. Djernes JK. Prevalence and predictors of depression in populations of elderly: a review. Acta Psychiatr Scand. 2006;113(5):372-87.

23. Zhao KX, Huang CQ, Xiao Q, Gao Y, Liu QX, Wang ZR, et al. Age and risk for depression among the elderly: a meta-analysis of the published literature. CNS Spectr. 2012;17(3):142-54.

24. Santos AT, Leyendecker DD, Costa AL, Souza-Talarico JN. Subjective memory complain in healthy elderly: influence of depressive symptoms, perceived stress and self-esteem. Rev Esc Enferm USP [Internet]. 2012 [cited 2014 Apr 22];46(n.spe):24-9. Available from: http://www.scielo.br/pdf/reeusp/v46nspe/en_04.pdf 